\title{
小倉充夫 著
}

\section{『南部アフリカ社会の百年 植民地支配・冷戦・市場経済』}

(東京大学出版会, 2009 年, A 5 判, 252 頁, 4,200 円)

山田信行

(駒澤大学文学部教授)

本書は, 主として労働移動に照準しながら, 南部アフリカ地域に属するザンビア の農村社会の変動をとらえようとした試みであり，日本における社会学においては， 数少ないアフリカを対象とした地域研究であるとともに, 著者が提唱する「国際社 会学」の実践例となっている.

まず，本書の内容を簡単に概観しよう。序章（「ザンビア農村社会と国際関係 一一課題と方法」）においては, 国際関係によって媒介されたものとして, 国民国 家内部における社会事象を把握しょうとする「国際社会学」の方法が初めに明示さ れる. ついで, 本書の主題である労働移動について, 南部アフリカにおいては植民 地期に農村からの労働移動が発生し, 還流型労働形態が主流化してきたことが指摘 される，そのうえで，農村に注目することによって，重層的な支配・被支配関係に 特徵づけられた, 南部アフリカとその「外部世界」との関係を明らかにし, そのこ とを通じて植民地支配，独立と冷戦，および市場経済化の意味を明らかにしようと する本書の課題が提示されている.

1 章「植民地期の労働移動と地域社会」においては, 対象としてのンセンガ（ザ ンビアの民族）の歴史と社会とが植民地行政官による記録に基づいて紹介される. この時期の労働移動は低賃金と雇用不足に起因し, 移動に伴って送り出し農村では 人口構成が変化して伝統システムが変容したことが指摘されている. さらに，送り 出しと受け入れに関して, 南部アフリカにおける労働移動は地域的重層性があるこ とが強調されたうえで，先の記録に基づいて，出稼ぎ労働者の経験が披歴される.

2 章「独立後の労働移動と地域社会」においては, ザンビアにおける南アフリカ や南ローデシアへの労働移動が地域間格差に由来することが指摘され, 労働移動の 帰結としての都市における定住も, 実際には農村との紐帯を維持しつつ営まれてい ることが, 現地調査に基づいて強調される. ついで, 還流型の移動が維持されつつ も, 出稼ぎ期間が長期化する傾向があることが指摘され，その一因としてザンビア 農村に存続する「呪術」(「伝統的」規範意識) が影響を与えているという興味深い 指摘がなされる.

3 章「経済改革と農村社会」においては, 独立以後のザンビアにおける, 銅採掘 に依存した経済からの脱却の試みが紹介されたあとで, 経済への国家介入が拡大し た帰結として財政赤字と生産停滞がもたらされたことが指摘される.1980 年代か 
ら始まる「構造調整」は, 企業の民営化などを進め, そうした行き詰まりからの転 換を意図していたものの, かえって地域間の格差や失業の増大などのネガティブな 効果をもたらしたという。 そうした文脈に拈いて, 村からの移動の多様性（移動先 の変化など）や農村工業の役割などが実態調査をふまえて分析されている.

4 章「民主化と民族間関係」においては，前章において分析された経済過程にか わって政治過程が分析される．南部アフリカにおける独立の過程が紹介されたあと で, 対外的脅威とソ連・東欧の影響を背景として, ザンビアにおける多民族を背景 にした複数政党制から一党制への移行過程が辿られている. そのうえで, 経済危機 を背景とする労働者や都市市民の反発によって, 一党制からふたたび複数政党制に 回帰する民主化が進展していく過程が記述される，民族間関係については，ザンビ アにおいては深刻な対立はないことが指摘されるとともに, 各民族間の好感度につ いての調査結果が紹介されている.

最後に終章「農村社会の新たな百年」においては，今後のザンビアにおける農村 社会が展望される，国際関係についていえば，鉱物資源を対象とした直接投資のあ りかたをみるかぎり, 現在においてもこれまでの 100 年間とあまり変化がないこと が指摘される，そのうえで，新たな変化として，アフリカにとって重要なヨーロッ パとの関係が不正移民の増加によって問題化しつつあることや，中国に代表される アジアとの関係が緊密化していることも指摘されている.いずれにせよ，アフリカ における国民国家形成の恣意性が民族の多文化性と統合とのジレンマを招来してい ることが確認される.

以上のような内容紹介をふまえて，若干のコメントを試みよう．本書は，もとも と様々な時期に執筆された独立した論文を編集した著作であるために，どちらかと いえば様々な論点が一般的かつ（重層的というよりは）並列的に記述されていて, 1 つの主題を解明するためにそうした論点が有機的に連関するように議論が展開さ れていない印象がある.

しかし，本書は世界システムにおける周辺社会の変動をとらえる際に求められる 基本的な視角が的確にふまえられており，国内の経済・政治，さらには南部アフリ カおよびかつての宗主国との国際関係が, ザンビア農村社会に様々な影響を与えて いる実態にバランスよく目を配った好著となっている. 労働力の移動についても, 日本においては, どちらかといえば先進社会における問題群に研究が集中する傾向 があるなかで, 本書はザンビアという発展途上社会の農村に焦点をあてた，送り出 し側に注目した研究であり，そのような意味でも一読に值しょう. 